DOI: 10.17117/na.2016.04.03.407

http://ucom.ru/doc/na.2016.04.03.407.pdf

Поступила (Received): 24.04.2016

\title{
Ярохно Н.H.
}

\section{Сосудистая реактивность и сердечный белок, связывающий жирные кислоты в диагностике, и прогнозе сердечно-сосудистых заболеваний}

\author{
Yarokhno N.N. \\ Vascular reactivity and heart protein, binding fatty acid in \\ the diagnosis and prognosis of cardiovascular diseases
}

В статье описаны исследования по оценке сосудистой реактивности для диагностики и прогноза сердечно-сосудистых заболеваний. Представлена информация о экспресс-тесте для ранней диагностики инфаркта с помощью сердечного белка, связывающего жирные кислоты Ключевые слова: сердечно-сосудистые заболевания, сосудистая реактивность, сердечный белок, связывающий жирные кислоты

\section{Ярохно Наталья Николаевна}

Доктор медицинских наук, профессор, старший научный сотрудник

Научно-исследовательский институт терапии и профилактической медицины

г. Новосибирск, ул. Бориса Богаткова, 175/1
This article describes study to assess vascular reactivity for the diagnosis and prognosis of cardiovascular diseases. The information on rapid test for the early detection of myocardial infarction with the help of a heart protein, binding fatty acid is presented

Key words: cardiovascular diseases, vascular reactivity, heart protein, binding fatty acid

\author{
Yarokhno Natalya Nikolaevna \\ Doctor of Medical Sciences, Professor, Senior \\ Researcher \\ Research institute of therapy and preventive \\ medicine \\ Novosibirsk, Borisa Bogatkova st., 175/1
}

Целью статьи является обобщение результатов исследований сосудистой реактивности и сердечного белка, связывающего жирные кислоты (сБСЖК) для определения перспектив их использования в диагностике и прогнозе течения основных сердечно-сосудистых заболеваний (ССЗ).

Ранее выявлено, что сосудистая реактивность (СР) к эндотелий-зависимым вазоактивным веществам (ВАВ) обладает прогностической значимостью при нестабильной стенокардии. У больных с летальными исходами этого состояния отмечается низкая СР к норадреналину, а также прессорная реакция на гистамин $[1,2]$. Определено, что низкий уровень соотношения СР к норадреналину, а также к гистамину является маркером многих осложнений инфаркта миокарда (ИМ) $[3,4,5]$. Разработаны диагностические технологии с нагрузкой хлористым натрием для диагностики ранних нарушений водно-солевого баланса на ранних стадиях артериальной гипертонии (АГ), в также при ее сочетании с вегето-сосудистыми дисфункциями $[6,7,8,9,10]$. Оценка СР к ВАВ проводится с 
применением лазерной допплеровской флуометрии, а также радиоизотопным методом [11,12]. Эти методические подходы используются для дифференцированного назначения гипотензивных препаратов на основе оценки СР у больных АГ, а также для модификации факторов риска ССЗ $[13,14,15,16]$. Апробирован отечественный экспресс-теста по определению сердечного белка, связывающего жирные кислоты («КардиоБСЖК»), продемонстрирована его высокая диагностическая значимость в ранней верификации ИМ $[17,18,19]$. Созданы модели использования вышеуказанных диагностических технологий в практическом здравоохранении [20,21,22]. В этих моделях могут быть использованы и ранее предложенные алгоритмы диагностики наследственных нарушений соединительной ткани, часто сочетаемых с ССЗ [23].

Таким образом, применение сосудистой реактивности и сердечного белка, связывающего жирные кислоты оптимизирует диагностику, прогноз, а также подбор лечения при основных сердечно-сосудистых заболеваниях.

\section{Список используемых источников:}

1. Николаева А.А., Николаев К.Ю., Николаева Е.И. и др. Соотношение сосудистой реактивности с липидным спектром крови и состоянием перекисного окисления липидов при нестабильной стенокардии // Терапевтический архив. 1998. № 12. С.13-15.

2. Николаева А.А., Николаева Е.И., Попова Л.В. и др. Динамика адаптационных индексов, перекисное окисление липидов и антиоксидантная защита при нестабильной стенокардии // Кардиология. 1998. №7. C.16-20.

3. Николаева А.А., Лифшиц Г.И., Штеренталь И.Ш. и др. Особенности нейроэндокринных нарушений регуляции при остром инфаркте миокарда в зависимости от тяжести течения заболевания // Кардиология. 1993. №11. С. 60-63.

4. Николаева А.А., Лифшиц Г.И., Штеренталь И.Ш. и др. Особенности изменения гистаминсеротониновой системы у больных острым инфарктом миокарда в зависимости от тяжести течения заболевания // Кардиология. 1997. №1. С.41-44.

5. Николаева А.А., Лифшиц Г. И., Штеренталь И.Ш. и др. Прогностическая оценка сосудистой реактивности к вазоактивным веществам и клинического индекса тяжести у больных острым инфарктом миокарда // Кардиология .1991. №12. С. 21-24.

6. Штеренталь И.Ш., Николаев К.Ю., Мержиевская В.М. и др. Особенности реакции прессорных и депрессорных регуляторных систем на повышенный прием поваренной соли при пограничной артериальной гипертензии // Кардиология. 1991. №10. С.47-50.

7. Николаев К.Ю. Особенности гормональной и сосудистой реактивности на кратковременную нагрузку хлористым натрием у больных с пограничной артериальной гипертензией. Автореферат на соискание ученой степени кандидата медицинских наук. Новосибирск. 1992. 20 c.

8. Штеренталь И.Ш., Николаева А.А., Николаев К.Ю. и др.. Особенности гормональной и сосудистой реакции на кратковременную солевую нагрузку у больных пограничной артериальной гипертензией 8 зависимости от уровня психоэмоционального напряжения // Кардиология.1993. №10. С.35-38.

9. Штеренталь И.Ш., Николаева А.А., Николаев К.Ю. и др.. Особенности гормональной и сосудистой реакции на кратковременную солевую нагрузку у больных пограничной артериальной гипертензией в зависимости от уровня психоэмоционального напряжения // Кардиология.1995. №7. С.14-17. 10. Пиковская Н.Б., Подколодная О.А., Штеренталь И.Ш. и др. Межэндокринные взаимодействия у больных с пограничной артериальной гипертензией с синдромом вегетососудистой дистонии и без него // Физиология человека. 1995. №2. С.110-116.

11. Штеренталь И.Ш., Мержиевская В.М., Николаев К.Ю. и др. Ранняя диагностика нарушений сосудистой реактивности и ее гормональной регуляции // Медицинская радиология. 1990. №8. С.48-49. 12. Николаев К.Ю., Пархоменко Е.И., Лифшиц Г.И. и др. Воспроизводимость показателей эндотелийзависимой сосудистой реактивности микроциркуляторного русла // Омский научный вестник (приложение). 2005. №1 (30). С. 198-200. 
13. Николаева А.А., Николаев К.Ю., Попова Л.В. Сосудистая реактивность и эндотелиальные дисфункции при артериальной гипертензии и ишемической болезни сердца (диагностика, лечение, профилактика). Новосибирск: ГПНТБ СО РАН. 2006. 192с.

14. Николаев К.Ю., Николаева А.А., Скворцова Ю.Н., Куроедов А.Ю. Новые методические подходы к оценке сосудистого и гормонального баланса у лиц с артериальной гипертензией // Кардиология. 1998. №9.

C. 38-41.

15. Николаев К.Ю., Гичева И.М., Лифшиц Г.И., Николаева А.А. Микроциркуляторная эндотелийзависимая сосудистая реактивность и основные факторы риска // Бюллетень СО РАМН. 2006. №4. С.63-66. 16. Николаев К.Ю., Николаева А.А., Дашевская А.А. и др. Взаимосвязь сосудистой реактивности, центральной гемодинамики и реакции на физическую нагрузку при пограничной артериальной гипертензии различного течения // Кардиология. 1998. №5. С.35-38.

17. Ярохно Н.Н., Зырянова А.В., Николаев К.Ю. Определение сердечного белка, связывающего жирные кислоты при остром инфаркте миокарда с помощью качественного иммунохромотографического теста // Медико-биологические и социально-психологические проблемы безопасности в чрезвычайных ситуациях. 2009. № 4. С.24-27.

18. Мартынов А.И., Спасский А.А., Арутюнов Г.П. и др. Ранняя экспресс-диагностика острого инфаркта миокарда // Терапия. 2015. №3. С. 13-26.

19. Ярохно Н.Н., Бондарева З.Г., Николаев К.Ю. Острый инфаркт миокарда: новые возможности ранней диагностики, лечения и прогноза. Новосибирск: Сибмедиздат НГМУ, 2011. 200 с.

20. Николаева А.А., Николаев К.Ю., Отева Э.А. и др. Диагностические технологии при диспансеризации и первичной профилактике хронических неинфекционных заболеваний // Здравоохранение Российской Федерации. 2004. №2. С. 55-56.

21. Николаева А.А., Николаев К.Ю., Отева Э.А.. Новые медицинские технологии в профилактике сердечно-сосудистых заболеваний: подготовка врачебных кадров. Новосибирск: ГПНТБ СО РАН, 2007. $184 \mathrm{c}$.

22. Отева Э.А., Николаева А.А., Егорова Н.А. и др. Подходы к организации первичной профилактики сердечно-сосудистых заболеваний // Здравоохранение Российской Федерации. 2002. №1. С. 21-23. 23. Анастасьева В.Г., Белан Ю.Г., Бржеский В.В. и др. Наследственные нарушения соединительной ткани. Российские рекомендации // Функциональная диагностика. 2009. №3. С. 61-87.

(C) 2016, Ярохно H.H.

Сосудистая реактивность и сердечный белок, связывающий жирные кислоты в диагностике, и прогнозе сердечно-сосудистых заболеваний (c) 2016, Yarokhno N.N.

Vascular reactivity and heart protein, binding fatty acid in the diagnosis and prognosis of cardiovascular diseases 